\title{
Nuclear entry of hyperbranched polylysine nanoparticles into cochlear cells
}

This article was published in the following Dove Press journal:

International Journal of Nanomedicine

12 March 201 I

Number of times this article has been viewed

\author{
Weikai Zhang' \\ Ya Zhang' \\ Marian Löbler ${ }^{2}$ \\ Klaus-Peter Schmitz ${ }^{2}$ \\ Aqeel Ahmad ${ }^{3}$ \\ Ilmari Pyykkö' \\ Jing Zou' \\ 'Department of Otolaryngology, \\ University of Tampere, Medical \\ School, Tampere, Finland; ${ }^{2}$ University \\ of Rostock, Institute for Biomedical \\ Engineering, Rostock, Germany; \\ ${ }^{3}$ Department of Biomedical \\ Engineering and Computational \\ Science, Aalto University, \\ Espoo, Finland
}

Correspondence: Jing Zou

Department of Otolaryngology,

Medical School, University of Tampere,

33520 Tampere, Finland

Tel +358331164129

Fax +358335517700

Email jing.zou@uta.fi
Background: Gene therapy is a potentially effective therapeutic modality for treating sensorineural hearing loss. Nonviral gene delivery vectors are expected to become extremely safe and convenient, and nanoparticles are the most promising types of vectors. However, infrequent nuclear localization in the cochlear cells limits their application for gene therapy. This study aimed to investigate the potential nuclear entry of hyperbranched polylysine nanoparticles (HPNPs) for gene delivery to cochlear targets.

Methods: Rat primary cochlear cells and cochlear explants generated from newborn rats were treated with different concentrations of HPNPs. For the in vivo study, HPNPs were administered to the rats' round window membranes. Subcellular distribution of HPNPs in different cell populations was observed with confocal microscope 24 hours after administration.

Results: Nuclear entry was observed in various cochlear cell types in vitro and in vivo. In the primary cochlear cell culture, concentration-dependent internalization was observed. In the cochlear organotypic culture, abundant HPNPs were found in the modiolus, including the spiral ganglion, organ of Corti, and lateral wall tissues. In the in vivo study, a gradient distribution of HPNPs through different layers of the round window membrane was observed. HPNPs were also distributed in the cells of the middle ear tissue. Additionally, efficient internalization of HPNPs was observed in the organ of Corti and spiral ganglion cells. In primary cochlear cells, HPNPs induced higher transfection efficiency than did Lipofectamine ${ }^{\mathrm{TM}}$.

Conclusion: These results suggest that HPNPs are potentially an ideal carrier for gene delivery into the cochlea.

Keywords: gene therapy, hearing loss, cochlea, internalization, nanoparticles, nuclear localization

\section{Introduction}

Gene therapy is a potentially effective therapeutic modality for treating congenital and acquired hearing loss by either changing mutant genes or upregulating critical gene expression. ${ }^{1-3}$ Regarding the gene delivery vectors, several viral vectors, including adenovirus, ${ }^{4,5}$ adeno-associated virus, ${ }^{6-8}$ lentivirus, ${ }^{9}$ herpes simplex virus type 1 , and vaccinia virus, ${ }^{10,11}$ have shown encouraging results in gene therapy. However, their use is accompanied by potential toxicity, immunological complications, and insertional mutagenesis. ${ }^{12,13}$ Such genotoxic effects can result in oncogenesis or even death. ${ }^{14-16}$ Therefore, they are still not regarded as safe systems for inner ear gene delivery.

Consequently, nonviral gene delivery vectors are expected to be safer and more convenient. ${ }^{17}$ Nanoparticles are the most promising gene carriers among the nonviral gene delivery vectors. ${ }^{18,19}$ Potential candidate nanoparticles, lipid nanocapsules, were 
observed to distribute in the rat cochlear cell populations after round window membrane permeation. ${ }^{20}$ However, infrequent nuclear localization in the cochlear cells limits their application for gene therapy. Many studies have confirmed that in cells with cytoplasmic plasmid delivery mediated by nonviral vectors, only those with evidence of nuclear plasmid localization showed efficient transgene expression. ${ }^{21,22}$ Usually, transfection efficiency is facilitated in dividing populations of cells in which the nuclear envelope disassembles during mitosis, thus largely eliminating this barrier. Unfortunately, most cochlear cell populations, especially spiral ganglion cells and hair cells, which are targets for gene therapy, do not actively undergo cell division during the gene transfer process, making gene transfer mediated by cytoplasmic plasmid delivery difficult. Thus, nuclear plasmid delivery induced by nanoparticles may be an option to improve transgene expression in nondividing or growth-arrested cells. ${ }^{23}$

Cationic polymers were reported to be potential candidate nonviral vectors for nuclear delivery of plasmids which could promote transgene delivery to the nucleus in vitro. ${ }^{24-26}$ Hyperbranched polylysine nanoparticles (HPNPs) are dendritic polymers with imperfectly branched or irregular structures, which are polydispersed and can be prepared in a single step on a large scale. Studies of the effects of such polymers on nuclear internalization by cochlear cells and on cell toxicity are scarce. Therefore, the present study was designed to investigate the potential nuclear entry of HPNPs in cochlear cells using both in vitro and in vivo experiments and depict information for developing novel nanoparticles suitable for gene therapy in hearing loss. Nucleolin distribution in the cultivated cochlear cells was analyzed. Preliminary gene transfection mediated by HPNPs was tested in vitro. Furthermore, the viability of L929 mouse fibroblasts and cochlear cells treated by HPNPs was evaluated by CellQuanti-Blue reagent (BioAssay Systems, Hayward, CA) and propidium iodide, respectively.

\section{Materials and methods Synthesis of HPNPs}

HPNPs were synthesized by thermal polymerization of $L$-lysine hydrochloride and labeled with fluorescent dye, FITC (HPNPs without FITC tagging were used for gene transfection). The thermal polymerization of $L$-lysine hydrochloride was performed at $150^{\circ} \mathrm{C}$ in the presence of an alkaline metal base to neutralize the amine hydrochloride and to create the corresponding free amino acid base according to the procedure described by Scholl et al. ${ }^{27}$ Samples were purified by dialysis and gel filtration with a Sephadex column.
The final product was recovered with $85 \%$ yield as an orange powder. Before usage in vitro or in vivo, the powder was dissolved in phosphate-buffered saline, resulting in a molecular concentration of $10^{-3} \mathrm{~mol} / \mathrm{L}$. The molecular weight, average hydrodynamic diameter, and polydispersity index of the HPNPs were determined by dynamic light scattering (Zetasizer Nano ZS, Malvern Instruments Ltd, UK; $M_{n}=22,000 \mathrm{~g} /$ mol, hydrodynamic diameter $=73 \mathrm{~nm}$, polydispersity index $=1.9$ ). The zeta potential of polyplexes was also determined by dynamic light scattering. Encapsulation efficiencies of plasmid DNA were calculated indirectly from the amount of nonencapsulated plasmid DNA recovered in the supernatant samples collected upon centrifugation of the nanoparticles. The amount of recovered free plasmid DNA in the supernatant was determined by spectrophotometry (NanoDrop ${ }^{\circledR}$ ND-1000, Wilmington, DE). The encapsulation efficiency was calculated as the ratio of the plasmid DNA loaded into the HPNPs to the total amount of plasmid DNA used for the preparation of the original mixture. The physicochemical characterization of polyplexes formed by complexation of HPNPs and plasmid DNA is summarized in Table 1. The surface morphology of the HPNPs was evaluated by scanning electron microscopy (Zeiss ULTRAplus, Bayern, Germany), which showed spherical morphology and similar size to the dynamic light scattering measurement (Figure 1).

\section{Primary cochlear cell culture}

Thirteen newborn rats (1-5 days old) were decapitated after deep anesthesia and sterilization with $70 \%$ ethanol. The cochleae were isolated and cut into small pieces and then dissociated with a phosphate-buffered saline-based solution containing elastase $1 \mathrm{mg} / \mathrm{mL}$ (Sigma Aldrich, St Louis, MO), collagenase type I $1 \mathrm{mg} / \mathrm{mL}$ (Sigma Aldrich), and trypsin

Table I Physicochemical characteristics of hyperbranched polylysine nanoparticles loaded with pDNA (ie, pGeneClip ${ }^{\text {TM }}$ hMGFP)

\begin{tabular}{lllll}
\hline $\begin{array}{l}\text { HPNPs/pDNA } \\
(\mathbf{w} / \mathbf{w})^{a}\end{array}$ & $\begin{array}{l}\text { Mean } \\
\text { hydrodynamic } \\
\text { diameter }(\mathbf{n m})\end{array}$ & $\begin{array}{l}\text { Zeta } \\
\text { potential } \\
(\mathbf{m V})\end{array}$ & PDI & EE (\%) \\
\hline $\mathrm{I}: \mathrm{I}$ & $234 \pm 4.6$ & +17.1 & 0.192 & 83.4 \\
$2: 1$ & $155 \pm 2.3$ & +14.1 & 0.236 & 82.8 \\
$3: 1$ & $139 \pm 0.9$ & +19.8 & 0.204 & 85.5 \\
$4: 1$ & $147 \pm 3.8$ & +20.3 & 0.216 & 87.9 \\
$5: 1$ & $134 \pm 1.0$ & +23.3 & 0.222 & 92.6 \\
$6: 1$ & $137 \pm 18.9$ & +19.1 & 0.254 & 91.7 \\
\hline
\end{tabular}

Note: ${ }^{a} \mathrm{~N} / \mathrm{P}(\mathrm{w} / \mathrm{w})$ ratio of polyplexes was varied from I:I to 6:I (2.5 $\mu \mathrm{g}$ plasmid DNA and varying amounts of HPNPs were used to prepare the polyplexes).

Abbreviations: PDI, polydispersity index; EE, encapsulation efficiency; HPNPs, hyperbranched polylysine nanoparticles. 


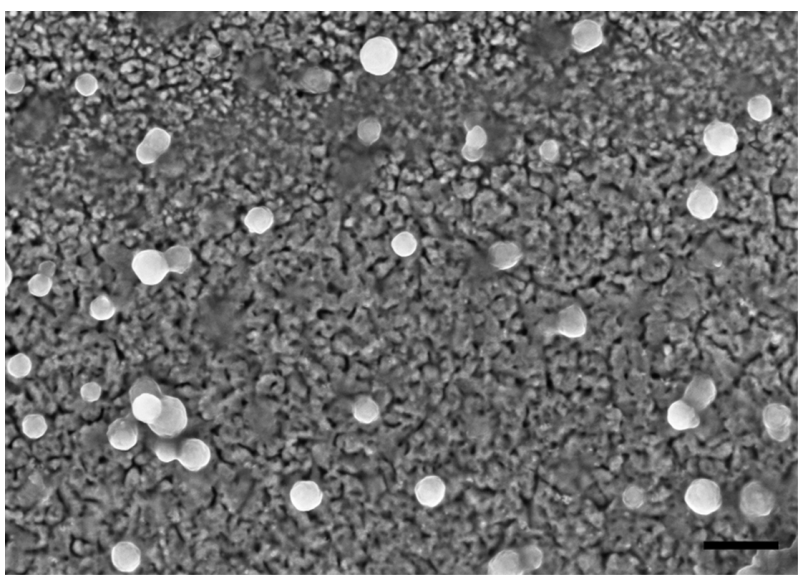

Figure I Scanning electron micrograph of hyperbranched polylysine nanoparticles. Scale bar $=200 \mathrm{~nm}$.

$0.5 \mathrm{mg} / \mathrm{mL}$ (Sigma Aldrich) for 30 minutes at $37^{\circ} \mathrm{C}$. The digestion was terminated by adding $1 \mathrm{~mL}$ DMEM-F12 (Sigma Aldrich) containing 10\% fetal bovine serum (Invitrogen, Carlsbad, CA). After centrifugation for five minutes at $250 \times g$, the cell pellets were resuspended in $1 \mathrm{~mL}$ of defined medium (DMEM-F12 with B27 supplement, 1 mM n-acetylL-cysteine, $1 \%$ penicillin-streptomycin, and $20 \mathrm{ng} / \mathrm{mL}$ epidermal growth factor [Sigma Aldrich]) and plated into a four-well Lab-Tek ${ }^{\circledR}$ II Chamber Slide (Nalge Nunc International, Naperville, IL) containing $1.0 \mathrm{~mL}$ defined medium/well. The cells were cultured at $37^{\circ} \mathrm{C}$ in a $\mathrm{CO}_{2}$ incubator overnight and then treated with HPNPs. HPNPs in defined cell culture medium with different concentrations (final concentrations: $3 \times 10^{-9} \mathrm{~mol} / \mathrm{L}, 6 \times 10^{-9} \mathrm{~mol} / \mathrm{L}, 1.2 \times 10^{-8} \mathrm{~mol} / \mathrm{L}, 2.4 \times 10^{-8} \mathrm{~mol} / \mathrm{L}$, $4.8 \times 10^{-8} \mathrm{~mol} / \mathrm{L}, 9.7 \times 10^{-8} \mathrm{~mol} / \mathrm{L}, 1.94 \times 10^{-7} \mathrm{~mol} / \mathrm{L}$, $3.87 \times 10^{-7} \mathrm{~mol} / \mathrm{L}, 7.74 \times 10^{-7} \mathrm{~mol} / \mathrm{L}, 1.55 \times 10^{-6}$ $\mathrm{mol} / \mathrm{L}, 3.13 \times 10^{-6} \mathrm{~mol} / \mathrm{L}, 5 \times 10^{-6} \mathrm{~mol} / \mathrm{L}, 6.25 \times 10^{-6} \mathrm{~mol} / \mathrm{L}$ ) were freshly prepared, and $1 \mathrm{~mL}$ of each solution was applied to one well of the slide. After 24 hours of cell growth under the same conditions, the cells were incubated in defined DMEM-F12 medium containing $5 \mu \mathrm{g} / \mathrm{mL}$ propidium iodide (Sigma Aldrich) for 10 minutes, which was applied to evaluate the change in cell membrane permeability and to identify the nuclei of dying cells in a population. After washing with phosphate-buffered saline for $3 \times 1$ minutes, cells were fixed with $4 \%$ paraformaldehyde for 30 minutes. The nuclei were stained with 4', 6-diamidino-2-phenylindole (DAPI, $10 \mathrm{ng} / \mathrm{mL}$; Sigma Aldrich) for 10 minutes. Cells were then mounted with Fluoromount ${ }^{\mathrm{TM}}$ (Sigma Aldrich) for confocal microscopy (phosphate-buffered saline washes for $3 \times 5$ minutes were applied between each staining step). For nucleolin staining, the fixed cells were washed with phosphate-buffered saline for $3 \times 1$ minutes, incubated with $0.1 \%$ Triton X-100 for 15 minutes, preinoculated goat serum (diluted at 1:20) for 30 minutes, rabbit antinucleolin antibody (diluted at 1:100 with $0.1 \%$ bovine serum albumin in phosphate-buffered saline [Sigma Aldrich]) overnight, TRITC-conjugated goat antirabbit IgG (diluted at 1:400 with $0.1 \%$ bovine serum albumin in phosphate-buffered saline) for 60 minutes, and DAPI $10 \mathrm{ng} / \mathrm{mL}$ for 10 minutes. The cells were washed with phosphate-buffered saline containing $0.1 \%$ Tween 20 for $3 \times 2$ minutes between each step and finally mounted with Fluoromount for confocal microscopy. For a negative control, the primary antibody was replaced with $0.1 \%$ bovine serum albumin in phosphate-buffered saline.

\section{Cochlear organotypic culture}

Five newborn rats (1-5 days old) were decapitated after deep anesthesia and sterilization with $70 \%$ ethanol. Similar to the primary cochlear cell cultures, each cochlea was isolated, cut into 3-4 pieces, and plated into a four-well Lab-Tek ${ }^{\circledR} I I$ Chamber Slide (Nalge Nunc International) containing $1.0 \mathrm{~mL}$ defined medium/well. The cochlear tissues were cultured at $37^{\circ} \mathrm{C}$ in a $\mathrm{CO}_{2}$ incubator overnight and then treated with HPNPs at concentrations of $2.5 \times 10^{-6} \mathrm{~mol} / \mathrm{L}$ and $1 \times 10^{-5} \mathrm{~mol} / \mathrm{L}$ for 24 hours. At the end of the incubation, the cochlear tissues were washed with phosphate-buffered saline $3 \times 3$ minutes and fixed in $4 \%$ paraformaldehyde for 30 minutes. After washing with phosphate-buffered saline, a selection of the specimens were counterstained with TRITC-labeled phalloidin $50 \mu \mathrm{g} / \mathrm{mL}$ (Sigma Aldrich) for 40 minutes, DAPI $10 \mathrm{ng} / \mathrm{mL}$ for 10 minutes, and mounted with Fluoromount for confocal microscopy. The rest of the specimens were used for Myosin VIIA staining according to the following procedure. The specimens were incubated with $0.1 \%$ Triton $\mathrm{X}-100$ for 15 minutes, preinoculated goat serum (diluted to 1:20) for 30 minutes, rabbit antiMyosin VIIA antibody (diluted to 1:100 with $0.1 \%$ bovine serum albumin-phosphate-buffered saline) overnight, TRITC-conjugated goat antirabbit IgG (diluted to 1:400 $0.1 \%$ bovine serum albumin-phosphate-buffered saline) for 60 minutes, and DAPI $10 \mathrm{ng} / \mathrm{mL}$ for 10 minutes. The specimens were washed with phosphate-buffered saline containing $0.1 \%$ Tween 20 for $3 \times 2$ minutes between each step, and were finally mounted with Fluoromount for confocal microscopy.

\section{In vivo intratympanic HPNP administration}

Six male Sprague-Dawley rats (3-10 months old) weighing $400-750 \mathrm{~g}$ with a normal Preyer's reflex were supplied by the 
experimental animal unit, University of Tampere. All animal experiments were approved by the University of Tampere ethical committee. Animal care and experimental procedures were conducted in accordance with European legislation. For intratympanic administration of HPNPs, the animals were under general anesthesia (medetomidine $0.5 \mathrm{mg} / \mathrm{kg}$, Orion Pharma, Finland, and ketamine $75 \mathrm{mg} / \mathrm{kg}$, Pfizer AB, Finland, given intraperitoneally). After local analgesia with lidocaine, a retroauricular incision was used to expose the left bulla. A hole was drilled on the bulla with a $2 \mathrm{~mm}$ diameter burr. After visualizing the stapedial artery, the round window membrane was identified above the artery. A small piece of gelatin sponge pledget (approximately $8 \mathrm{~mm}^{3}$ after saturation) saturated with $10^{-3} \mathrm{~mol} / \mathrm{L}$ HPNPs was placed on the round window membrane for 24 hours. The operation was performed under sterile conditions. Atipamezole hydrochloride $2 \mathrm{mg} / \mathrm{kg}$ was injected intraperitoneally immediately after the operation to accelerate recovery from anesthesia. Saline $2 \mathrm{~mL}$ was administered by subcutaneous injection in the neck. L-Polamivet ${ }^{\circledR} 0.4 \mathrm{~mL} / \mathrm{kg}$ was injected twice a day to relieve pain. After 24 hours, following intraperitoneal injections of pentobarbital $60 \mathrm{mg} /$ $\mathrm{kg}$, the cochleae were fixed using cardiac perfusion with $4 \%$ paraformaldehyde, and the bullae were collected and further fixed for 60 minutes. The cochleae were thoroughly washed with tap water for 30 seconds, opened by breaking the bony wall under a stereomicroscope, and then washed again with phosphate-buffered saline for $2 \times 5$ minutes. The bullae were incubated with DAPI $10 \mu \mathrm{g} / \mathrm{mL}$ for 10 minutes to stain the nuclei. After washing with phosphate-buffered saline for $3 \times 5$ minutes, the round window membrane, stapedial artery, middle ear mucosa, lateral wall, and modiolus, together with the basilar membrane, were harvested using a stereomicroscope, placed on glass slides, and mounted with Fluoromount for confocal microscopy.

\section{Cytotoxicity test in mouse fibroblasts}

L929 mouse fibroblasts (American Type Culture Collection number CCL 1, DSMZ, Braunschweig, Germany) were cultured in DMEM culture medium (AppliChem, Darmstadt, Germany) containing $4.5 \mathrm{mg} / \mathrm{mL}$ glucose, $10 \%$ fetal calf serum, $100 \mathrm{U} / \mathrm{mL}$ penicillin $\mathrm{G}, 100 \mu \mathrm{g} / \mathrm{mL}$ streptomycin (PAA Laboratories, Cölbe, Germany), and $\mathrm{NaHCO}_{3} 3.7 \mathrm{~g} / \mathrm{L}$ at $37^{\circ} \mathrm{C}, 5 \% \mathrm{CO}_{2}$, and $95 \%$ humidity. Cells were harvested by trypsinization (PAA Laboratories) and seeded at a density of 2000 cells/well into a 96-well microtiter plate (Greiner Bio-one, Frickenhausen, Germany). The cells were cultured under the above conditions for 24 hours and then treated with HPNPs. HPNPs were freshly prepared with cell culture medium at different concentrations (final concentrations were $10^{-4} \mathrm{~mol} / \mathrm{L}, 10^{-5} \mathrm{~mol} / \mathrm{L}, 10^{-6} \mathrm{~mol} / \mathrm{L}$, $10^{-7} \mathrm{~mol} / \mathrm{L}, 10^{-8} \mathrm{~mol} / \mathrm{L}, 10^{-9} \mathrm{~mol} / \mathrm{L}, 10^{-10} \mathrm{~mol} / \mathrm{L}, 10^{-11} \mathrm{~mol} / \mathrm{L}$, $10^{-12} \mathrm{~mol} / \mathrm{L}, 10^{-13} \mathrm{~mol} / \mathrm{L}$ ), and $200 \mu \mathrm{L}$ of each solution was applied to one well of the microtiter plate. After 48 hours of incubation, the medium containing HPNPs was replaced by fresh medium containing 10\% CellQuanti-Blue reagent, and the cells were cultivated for another two hours. Cellular reductase activity was quantified by resorufin fluorescence (Fluostar Optima, BMG, Offenburg, Germany; excitation wavelength $544 \mathrm{~nm}$, emission wavelength $590 \mathrm{~nm}$ ). Cellular uptake of FITC-tagged HPNPs was quantified by cell fluorescence measurements (excitation wavelength $485 \mathrm{~nm}$, emission wavelength $520 \mathrm{~nm}$ ).

\section{Preliminary HPNP-mediated gene transfection}

We purchased the plasmid pGeneClip ${ }^{\mathrm{TM}}$ hMGFP, which encodes a shRNA to silence the inhibitor of differentiation and DNA binding-2 (Id2) transiently, and express the reporter gene EGFP (SuperArray, Bioscience Corp, Frederick, MD). NIH 3 T3 cells (American Type Culture Collection, Manassas, VA) were cultured in flasks containing DMEM (Sigma Aldrich) supplemented with $10 \%$ fetal bovine serum (Invitrogen) and $4 \mathrm{mM}$ L-glutamine (Sigma Aldrich). Four hours before transfection, the cells are trypsinized and replated into 12 -well plates at a density of $3.5 \times 10^{5}$ cells per well in $1 \mathrm{~mL}$ of fresh medium. For each well to be transfected, $2.5 \mu \mathrm{g}$ plasmid DNA and varying amounts of HPNPs $(\mathrm{N} / \mathrm{P}(\mathrm{w} / \mathrm{w})$ ratios of polyplexes varied from 1:1 to $6: 1)$ were added separately to $50 \mu \mathrm{L}$ of $150 \mathrm{mM} \mathrm{NaCl}$. Prior to addition to the culture, HPNP solution was added to the plasmid DNA solution and allowed to stand at room temperature for 10 minutes. At four hours after transfection, another $1 \mathrm{~mL}$ fresh medium was added to the well, and the cells were incubated as before. Cochlear cells were also transfected with the pGeneClip hMGFP plasmid using HPNPs at an $\mathrm{N} / \mathrm{P}$ (w/w) ratio of 5:1 and Lipofectamine 2000 (Invitrogen), respectively. Lipofectamine-mediated transfection was performed according to the manufacturer's instructions. After 24 hours of transfection, the cells were fixed using $4 \%$ paraformaldehyde. The nuclei were counterstained with DAPI for 10 minutes. Finally, the cells were mounted with Fluoromount for confocal microscopy.

\section{Confocal microscopy}

The specimens were observed under an Olympus IX70 microscope with ANDOR IQ installed. The excitation filters 
were $488 \mathrm{~nm}$ (blue excitation) and $568 \mathrm{~nm}$ (green excitation), and an Ar-Kr laser was used as the excitation source. The corresponding emission filters were 525/50 (FITC) and 607/45 (TRITC). DAPI was excited with a 340-380 nm filter and detected using a 500 LP filter. The signal intensity was analyzed with Image J software.

\section{Statistical analysis}

Cells expressing green fluorescent protein were counted as positive cells and cells with DAPI-counterstained nuclei were defined as total number of cells $\left(10^{4}\right.$ cells were counted) using Image J software. Transfection efficiencies were calculated by dividing the number of green fluorescent protein positive-cells by the total number of cells. The signal intensity was corrected by the intensity of a randomly selected background region. The corrected mean values were analyzed with the SPSS program (v. 11.5, Chicago, IL). Differences in the levels of signal intensity among concentrations and cell populations were analyzed by analysis of variance. $P<0.05$ was accepted as an indication of statistical significance.

\section{Results}

\section{Internalization of HPNPs in primary cochlear cells}

After 24 hours of incubation, efficient internalization of HPNPs was observed in primary rat cochlear cell cultures at all tested concentrations. The amount of HPNPs internalized by the cells was dosage-dependent, which means that the higher concentration of HPNPs applied to the medium, the greater the fluorescent intensity in the cochlear cells. This positive correlation was statistically significant $(P<0.001$, analysis of variance, Figure 2). Nuclear entry of HPNPs was detected in different types of cochlear cells, including the hair cells and spiral ganglion cells at different concentrations (Figures 3-5). The higher the concentration of HPNPs, the more nuclear localization was observed (Figure 3). In the cochlear cells that were incubated with HPNPs at concentrations from $3.87 \times 10^{-7} \mathrm{~mol} / \mathrm{L}$ to $6.25 \times 10^{-6} \mathrm{~mol} / \mathrm{L}$, homogenous and condensed distribution of HPNPs was detected in the entire nuclei (Figures 4 and 5). Nuclear permeation of propidium iodide, which indicates cell death, was also observed in cochlear cells treated with HPNPs at concentrations from $3.87 \times 10^{-7} \mathrm{~mol} / \mathrm{L}$ to $6.25 \times 10^{-6} \mathrm{~mol} / \mathrm{L}$ (Figures 4 and 5). In the outer hair cells, condensed distribution of HPNPs was visualized in the upper part of the cell body including cuticular plates, and nuclei. HPNP vesicles appeared in the hair bundles (Figures 5A-C).

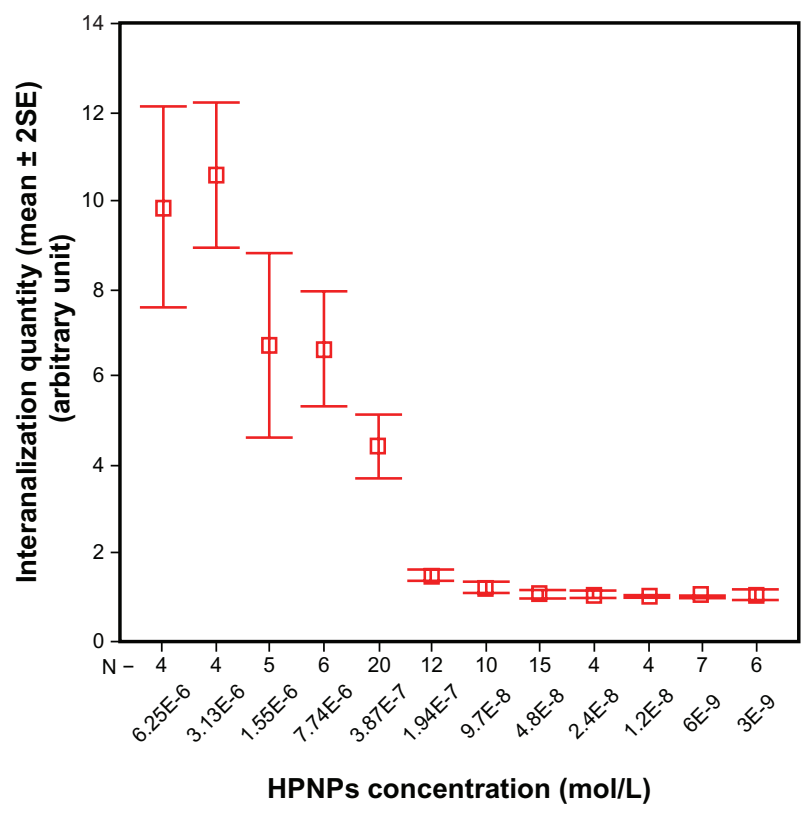

Figure 2 Concentration-dependent internalization of hyperbranched polylysine nanoparticles in primary cochlear cell culture.

In the inner hair cells, cytoplasmic vesicles and condensed homogenous nuclear distribution of HPNPs were observed (Figures 5D-F). HPNPs were included in both cytoplasmic and nuclear vesicles when the cochlear cells were treated with HPNPs at concentrations below $3.87 \times 10^{-7} \mathrm{~mol} / \mathrm{L}$ (Figure 3 ). No permeation of propidium iodide was detected in the nuclei when the HPNPs concentration was lower than $3.87 \times 10^{-7} \mathrm{~mol} / \mathrm{L}$, indicating that these cells were alive. Furthermore, the HPNP vesicles also indicate active nuclear entry of HPNPs into living cells instead of passive diffusion of HPNPs into the nuclei of dead cells in which homogenous and condensed distribution of HPNPs was detected in the entire nuclei (Figures 4G-I). However, nuclear permeation of propidium iodide was occasionally observed in spiral ganglion cells treated with HPNPs at a concentration of $9.7 \times 10^{-8} \mathrm{~mol} / \mathrm{L}$ (Figures $5 \mathrm{G}-\mathrm{I}$ ). Scarce perinuclear distribution of propidium iodide dots, together with HPNP vesicles, was observed in the cochlear cells (Figure 3B). Interestingly, nuclei compressed by HPNP vesicles and permeated with propidium iodide were also observed (Figures 5J-M). Nucleolin expression was detected in the cochlear cells. The subcellular distribution of nucleolin was in both the cytoplasm and nucleus (Figure 6). In the nucleus, most nucleolin was localized and condensed in the nucleolus. A HPNP vesicle pathway from the cytoplasm towards the nucleolin-positive nucleolus was also observed (Figure 6). Nucleolin was not detected in the negative control specimens. 

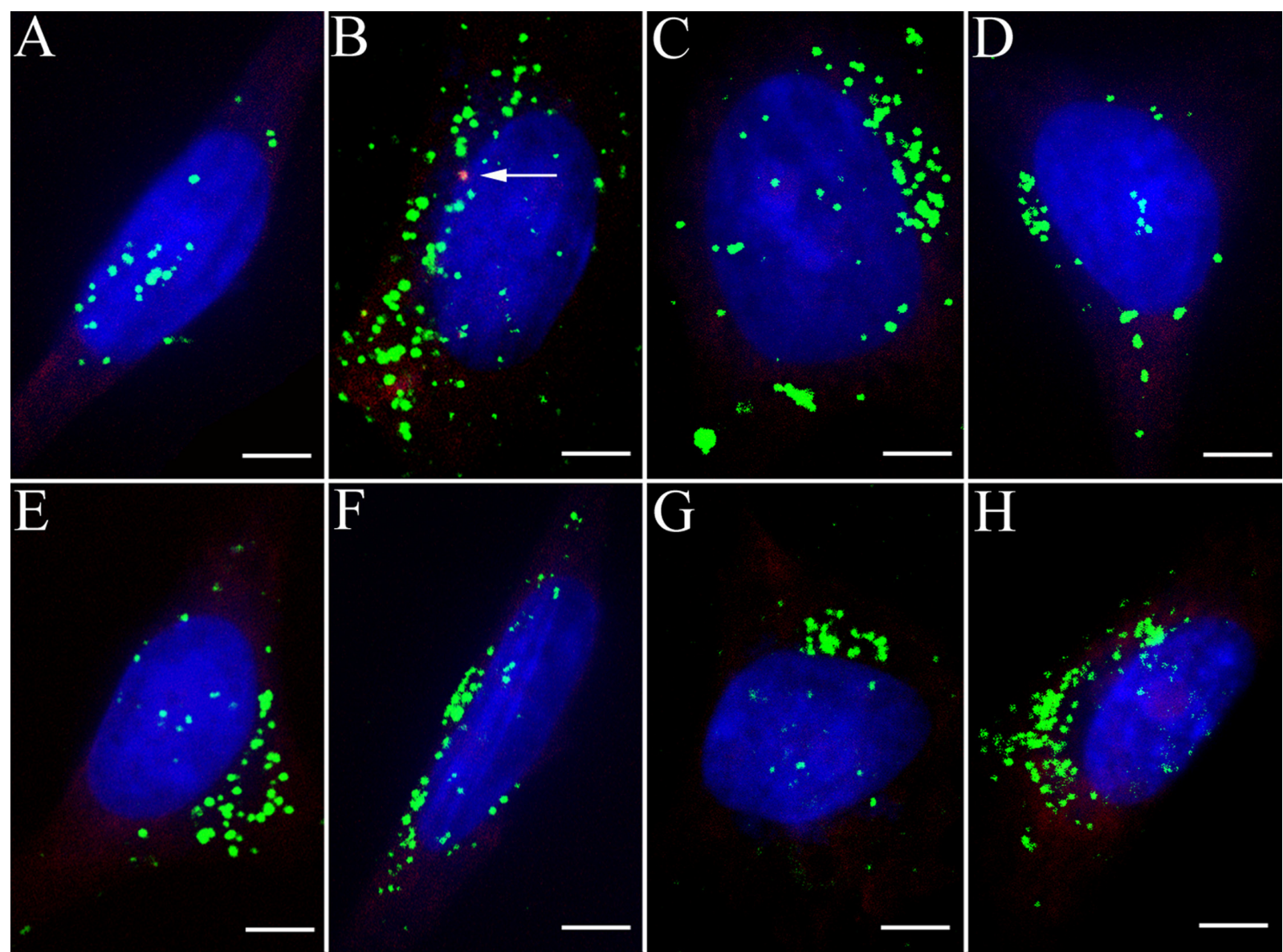

Figure $3 \mathrm{HPNP}$ vesicle formation in both the cytoplasm and nuclei was observed at concentrations below $3.87 \times 10^{-7} \mathrm{~mol} / \mathrm{L}[\mathbf{A}) 3.87 \times 10^{-7} \mathrm{~mol} / \mathrm{L}$, B) $1.94 \times 10^{-7} \mathrm{~mol} / \mathrm{L}$, C) $9.7 \times 10^{-8} \mathrm{~mol} / \mathrm{L}$, D) $4.8 \times 10^{-8} \mathrm{~mol} / \mathrm{L}$, E) $2.4 \times 10^{-8} \mathrm{~mol} / \mathrm{L}$, F) $1.2 \times 10^{-8} \mathrm{~mol} / \mathrm{L}$, G) $6 \times 10^{-9} \mathrm{~mol} / \mathrm{L}$, and $\left.\left.\mathbf{H}\right) 3 \times 10^{-9} \mathrm{~mol} / \mathrm{L}\right]$. Nuclear permeation of propidium iodide was not detected in these cells. Perinuclear distribution of dot-like propidium iodide vesicle was observed in B (arrow).

Notes: Green: FITC-conjugated HPNPs. Red: propidium iodide permeation. Blue: nuclear staining by DAPI. Scale bar $=5 \mu \mathrm{m}$

Abbreviation: HPNPs, hyperbranched polylysine nanoparticles.

\section{HPNPs internalization in rat cochlear organotypic culture}

In cochlear organotypic culture treated with HPNPs for 24 hours, abundant HPNPs appeared in diverse cell types of the modiolus, organ of Corti, and the lateral wall (Figure 7). The hair cell region was demonstrated by Myosin VIIA staining (Figures 7A and B). Nuclear entry of HPNPs was frequently observed in these different cell types.

\section{HPNPs in adult rat cochlear cells after round window membrane permeation}

HPNPs were observed in the round window membrane, middle ear mucosa, organ of Corti, spiral ganglion, stria vascularis, spiral ligament, and stapedial artery cells at 24 hours after round window membrane administration. HPNPs appeared in both layers of the round window membrane (Figure 8A). Homogenous condensed distribution of HPNPs was detected in the nuclei, and cytosolic
HPNP vesicles were traveling from the outer layer towards the inner layer (Figure 8A). Additionally, there was a gradient of cytosolic HPNP vesicles from the outer layer to the inner layer (Figure 8A). More pronounced nuclear entry was also observed in the outer layer of the round window membrane than in the inner layer. In the middle ear mucosal cells, HPNPs were observed in both the cytoplasm and nuclei (Figure 8B). The distribution was condensed in the nuclei, and there was a very small amount of vesicles in the cytoplasm. In the spiral ganglion cells, perinuclear distribution of HPNP vesicles was observed (Figure 8C). In the organ of Corti, HPNPs were detected in the cytoplasm of outer hair cells, inner hair cells, and supporting cells (Figure 8D). In the stria vascularis, HPNP vesicles appeared in the tight junctions, cytoplasm, and perinuclear region of the marginal cells (Figure 8E). In the spiral ligament fibrocytes, HPNPs mainly appeared in the cytoplasm as vesicles (Figure 8F). Abundant HPNPs were also detected in the stapedial artery 

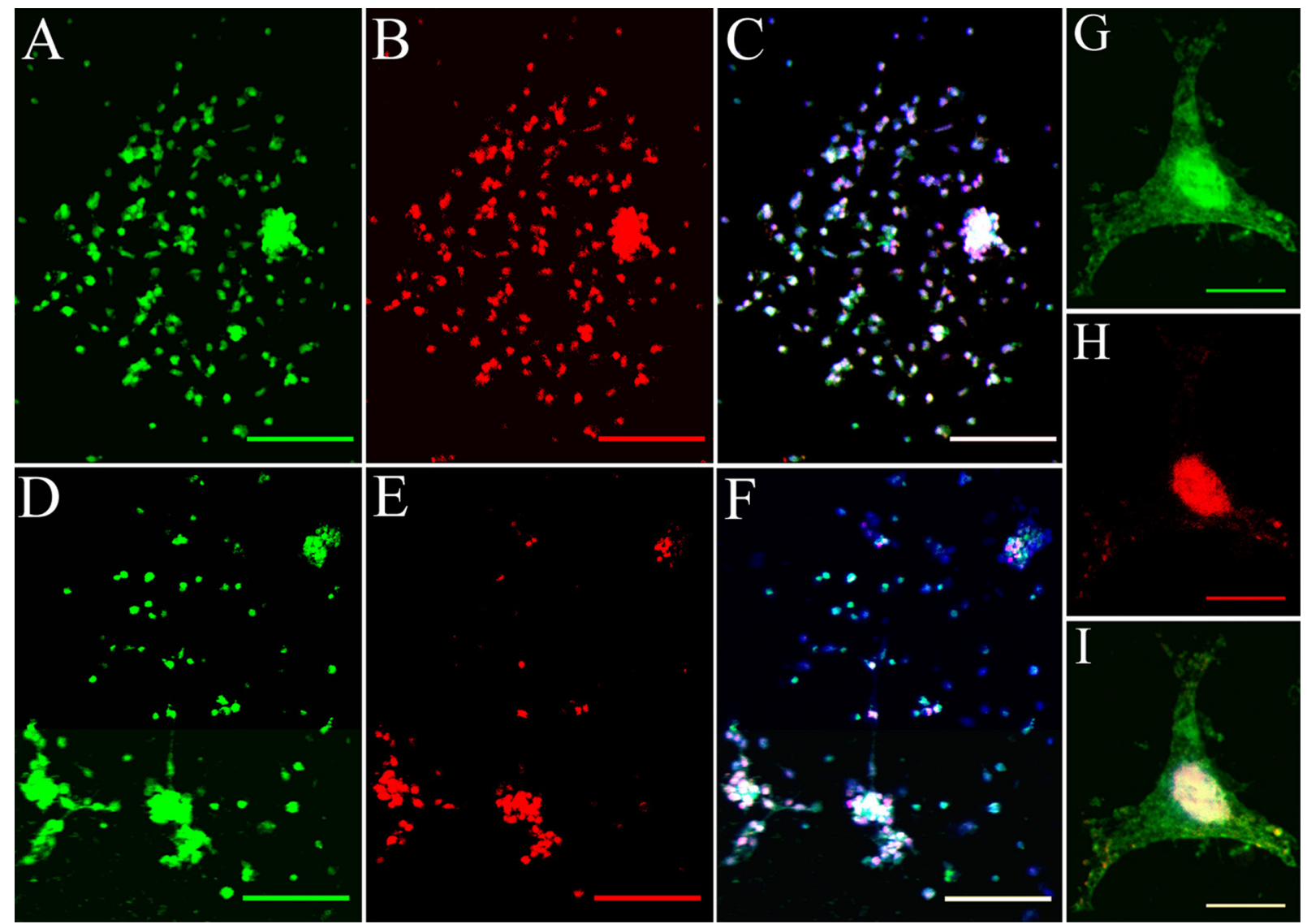

Figure 4 Internalization of HPNP-induced permeation of propidium iodide in primary cochlear cell culture. A-C) The cochlear cells were incubated with HPNPs at a concentration of $6.25 \times 10^{-6} \mathrm{~mol} / \mathrm{L}$. B) Nuclear permeation of propidium iodide was observed in all the tested cells. C) Shows the merged images of A and B. D-F) The cochlear cells were incubated with HPNPs at a concentration of $3.87 \times 10^{-7} \mathrm{~mol} / \mathrm{L}$. E) Nuclear permeation of propidium iodide was observed in most of the cells. F) Shows the merged images of $\mathbf{D}$ and $\mathbf{E}$. G-I) Internalization of HPNP-induced permeation of propidium iodide in a single cell (higher magnification) at a concentration of $6.25 \times 10^{-6} \mathrm{~mol} / \mathrm{L}$. G) Homogenous and condensed distribution of HPNPs was detected in the cytoplasm and entire nucleus. I) Shows the merged images of $\mathbf{G}$ and $\mathbf{H}$.

Notes: Green: FITC-conjugated HPNPs. Red: propidium iodide permeation. Blue: nuclear staining by DAPI. Scale bars: $\mathbf{A}-\mathbf{F}=100 \mu \mathrm{m}, \mathbf{G}-\mathbf{I}=10 \mu \mathrm{m}$.

Abbreviation: HPNPs, hyperbranched polylysine nanoparticles.

cells and appeared as vesicles in both the cytoplasm and nuclei (Figure 8G).

\section{Cytotoxicity of HPNPs in L929 cells}

HPNPs at concentrations up to $10^{-7} \mathrm{~mol} / \mathrm{L}$ were not toxic to L929 cells (Figure 9). However, higher concentrations of HPNPs showed low cytotoxicity, yielding an $\mathrm{ED}_{50}$ of $10^{-6.2} \mathrm{~mol} / \mathrm{L}$. HPNPs labeled with FITC were visualized inside cells by confocal microscopy. The amount of HPNPs internalized by the cells was dosage-dependent, which was consistent with the results from the primary cochlear cells. The cell death rate was correlated with the HPNP internalization rate at concentrations up to $10^{-5} \mathrm{~mol} / \mathrm{L}$.

\section{HPNPs-mediated transfection of the pGeneClip hMGFP plasmid in vitro}

After 24 hours of incubation, NIH $3 \mathrm{~T} 3$ cells were transfected with the pGeneClip hMGFP plasmid using HPNPs.
To determine the optimum N/P (w/w) ratio, the N/P (w/w) ratio was varied from $1: 1$ to $6: 1$. N/P $(\mathrm{w} / \mathrm{w})$ ratios of $4: 1$ and 5:1 resulted in the maximal level of green fluorescent protein expression. HPNP-mediated transfection efficiency in NIH 3 T3 cells was $29.8 \%$ at an N/P (w/w) ratio of 5:1 (Figure 10A). HPNP-mediated transfection efficiency in primary cochlear cell culture was $8.7 \%$ at an $\mathrm{N} / \mathrm{P}(\mathrm{w} / \mathrm{w})$ ratio of 5:1 (Figure 10B), which was higher than the Lipofectamine-mediated transfection efficiency of $6.0 \%$ (Figure 10C).

\section{Discussion}

The success of nonviral gene therapy has been largely limited by inefficient gene delivery to cochlear cells due to the presence of the nuclear envelope barrier to gene transfer. The primary intention of this study was to demonstrate the potential of HPNPs as carriers for the delivery of genes to the nuclei of cochlear cells. Although it has been shown 

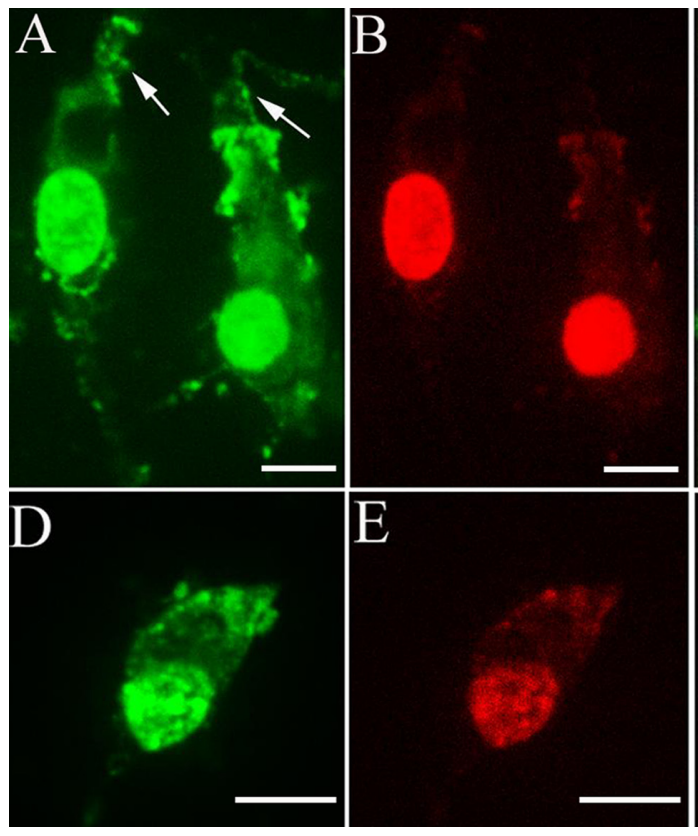
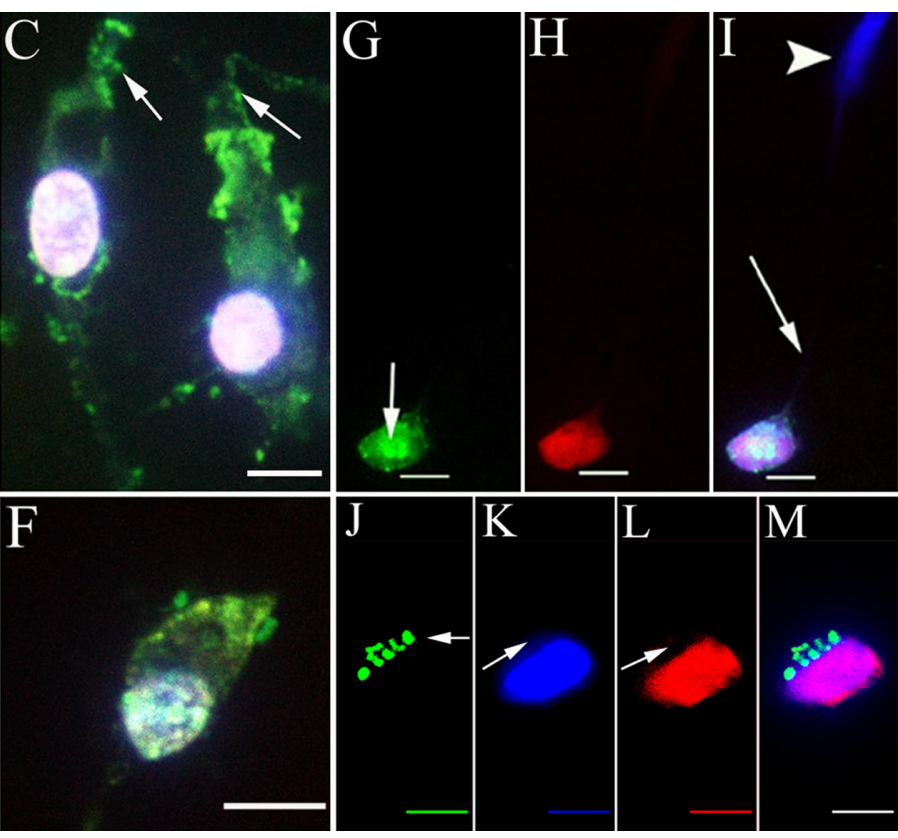

Figure 5 Death of different cochlear cell populations was induced by HPNP internalization. A-F) Internalization of HPNPs by the cochlear hair cell. Cytoplasmic vesicles and condensed homogenous nuclear distribution of HPNPs appeared in the outer hair cell incubated with $3.87 \times 10^{-7} \mathrm{~mol} / \mathrm{L} \mathrm{HPNPs}(\mathbf{A}-\mathbf{C})$ and inner hair cell incubated with $5 \times 10^{-6} \mathrm{~mol} / \mathrm{L}$ HPNPs (D-F). Vesicles were observed in the hair bundles (arrows in A and C). Figures B and $\mathbf{E}$ showed the permeation of propidium iodide. G-I) Spiral ganglion cell death was induced by HPNP internalization at a concentration of $9.7 \times 10^{-8} \mathrm{~mol} / \mathrm{L}$ (Arrow in $\mathbf{G}$ shows HPNPs in the neural soma of spiral ganglion cell). $\mathbf{H}$ ) Shows the permeation of propidium iodide. I) shows the merged images of $\mathbf{G}$ and $\mathbf{H}$ (Arrow: nerve fiber. Arrow head: nuclei of Schwann cell). J-M) The nucleus was compressed by HPNP vesicles, and propidium iodide permeated the nucleus when the cells were exposed to $3.87 \times 10^{-7} \mathrm{~mol} / \mathrm{L} \mathrm{HPNPs}$ (arrows). $\mathbf{M}$ is the merged image. Notes: Green: FITC-conjugated HPNPs. Red: propidium iodide permeation. Blue: nuclear staining by DAPI. Scale bars: $\mathbf{A}-\mathbf{C}=5 \mu \mathrm{m}, \mathbf{D}-\mathbf{F}=7 . \mathbf{I} \mu \mathrm{m}, \mathbf{G}-\mathbf{M}=5 \mu \mathrm{m}$. Abbreviation: HPNPs, hyperbranched polylysine nanoparticles.

that nanoparticles can enter the cytoplasm of cochlear cells, nuclear delivery remains problematic. ${ }^{20,28}$ HPNPs were detected in both the cytoplasm and nuclei of cochlear cells in primary cell culture, organotypic culture, and in vivo with intratympanic administration. The present results contrast with the results of an in vivo study performed in guinea pigs

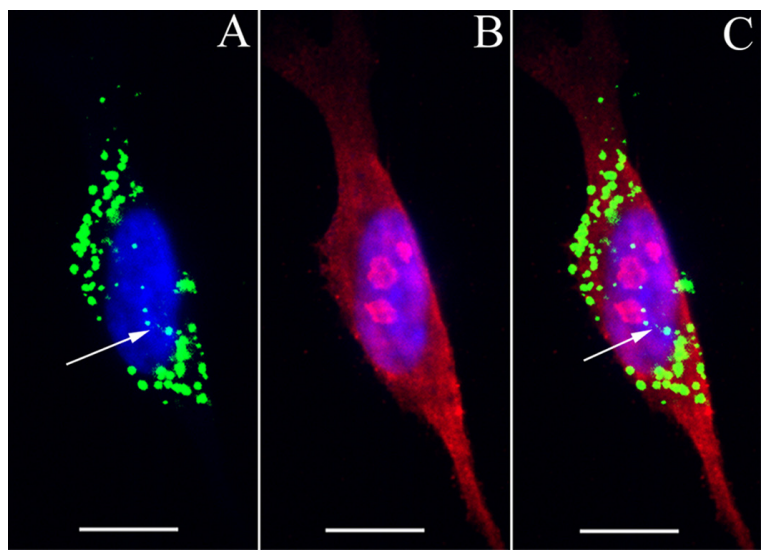

Figure 6 A HPNP vesicle pathway from the cytoplasm towards the nucleolinpositive nucleolus was observed in the primary cochlear cell culture exposed to HPNPs (arrows in $\mathbf{A}$ and $\mathbf{C}$ ).

Notes: Green: FITC-conjugated HPNPs. Red: nucleolin. Blue: nuclear staining by DAPI. Scale bar $=10 \mu \mathrm{m}$.

Abbreviation: HPNPs, hyperbranched polylysine nanoparticles. using HPNPs. ${ }^{28}$ Our explanation is that the nuclear entry of HPNPs is concentration-dependent; in the in vivo study, cochlear cells were exposed to much lower concentrations of HPNPs than in the in vitro study. The cells that are integrated in the organ may behave differently from individual cells. Nuclear localization of HPNPs was intense in the round window membrane cells of rats, but was rarely observed in the cochlear cells. The different methods of delivering the HPNPs and the biological differences between rats and guinea pigs should also be considered as an explanation for our results.

Concentration-dependent toxicity occurred in the primary cochlear cell culture, and most of the cells died when treated with HPNPs at the concentration of $3.87 \times 10^{-7} \mathrm{~mol} / \mathrm{L}$ $\left(10^{-6.4} \mathrm{~mol} / \mathrm{L}\right)$, whereas the $\mathrm{ED}_{50}$ for HPNP-treated $\mathrm{L} 929$ cells was $10^{-6.2} \mathrm{~mol} / \mathrm{L}$. This finding indicated that certain cell types in primary cochlear cell cultures may be more vulnerable to HPNP treatment than L929 cells. Spiral ganglion cells died when treated with HPNPs at a concentration of $9.7 \times 10^{-8} \mathrm{~mol} / \mathrm{L}$, which further supported this hypothesis, because neurons are highly sensitive to hazardous substance exposure. It seems contradictory that dead cells take up the highest amount of nanoparticles (Figure 9, 10 $0^{-5} \mathrm{~mol} / \mathrm{L}$ HPNPs). 

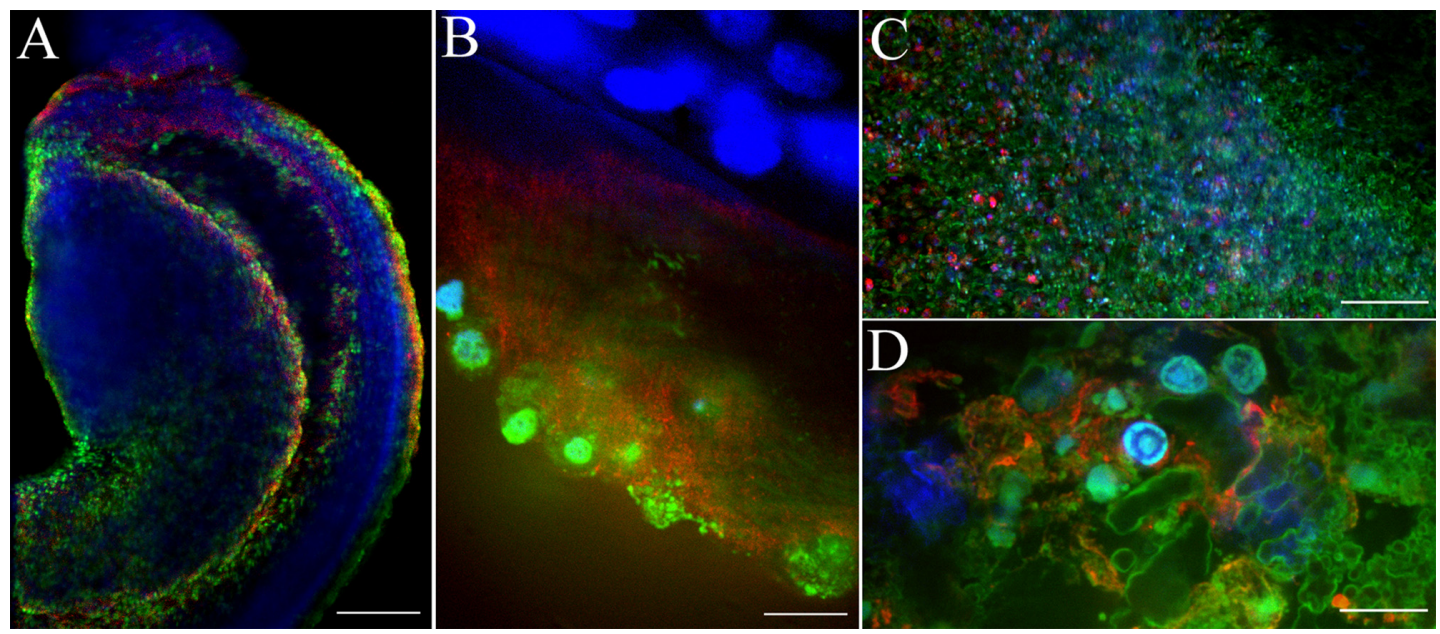

Figure 7 Uptake of HPNPs in the cochlear organotypic culture. The tissues were incubated with $2.5 \times 10^{-6} \mathrm{~mol} / \mathrm{L}(\mathbf{A}, \mathbf{B})$ and I $\times 10^{-5} \mathrm{~mol} / \mathrm{L}(\mathbf{C}, \mathbf{D}) \mathrm{HPNPs}$ for 24 hours. $\mathbf{A}$ and $\mathbf{B}$ are merged images of HPNPs, Myosin VIIA, and DAPI in the modiolus (A) and organ of Corti (B). C) low magnification and $\mathbf{D})$ higher magnification are merged images of HPNPs, F-actin, and DAPI in the lateral wall.

Notes: Green: FITC-conjugated HPNPs. Red: Myosin VIIA (A, B), F-actin stained by TRITC-conjugated phalloidin (C, D). Blue: nuclear staining by DAPI. Scale bars: A, $\mathbf{C}=103.4 \mu \mathrm{m}, \mathbf{B}, \mathbf{D}=10 \mu \mathrm{m}$.

Abbreviation: HPNPs, hyperbranched polylysine nanoparticles.
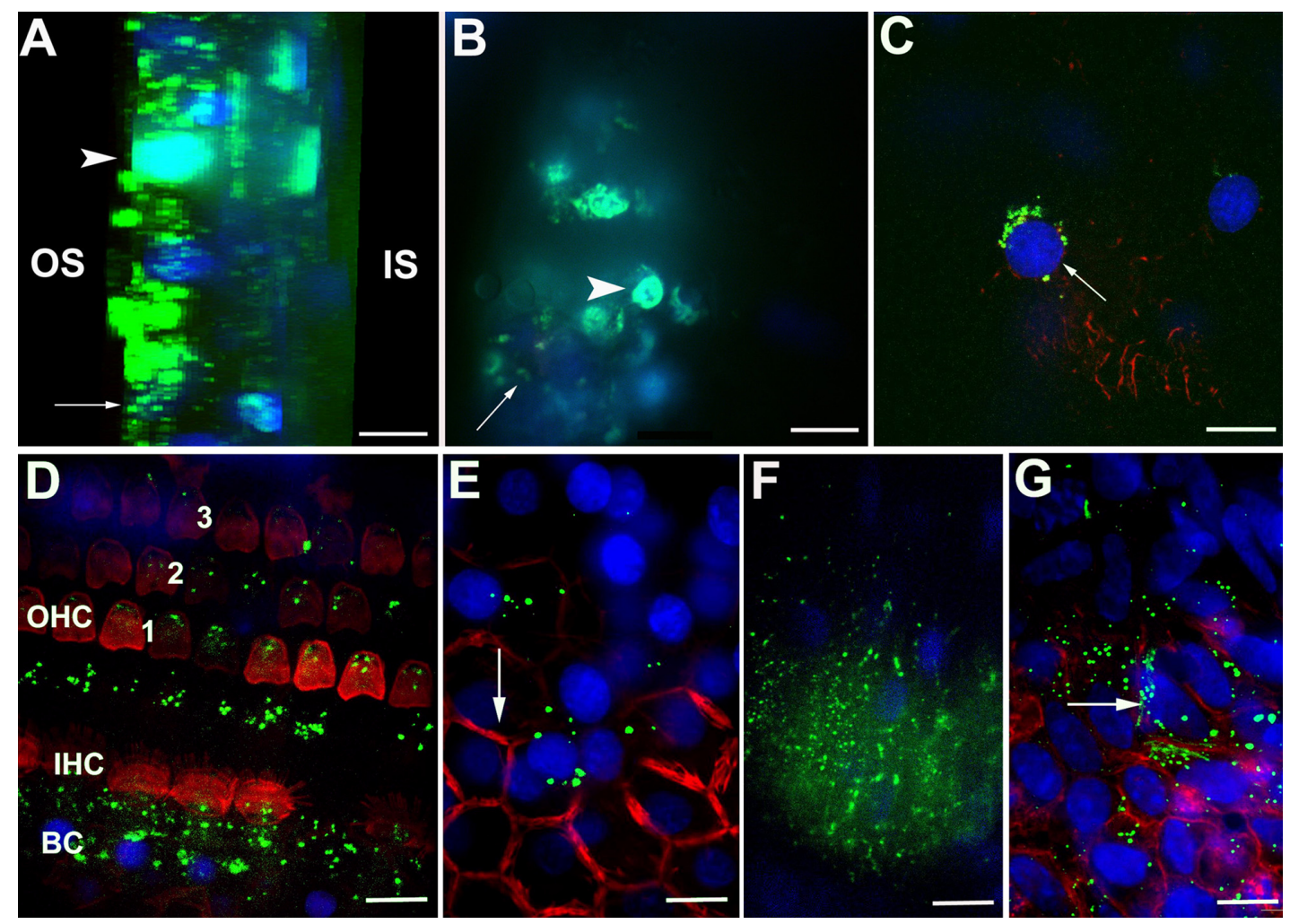

Figure 8 Uptake of HPNPs in the cochlea 24 hours after round window membrane administration in an adult rat. A gelatin sponge was immersed in $10^{-3}$ mol/L HPNPs and placed on the round window membrane. A) Lateral view of reconstructed three-dimensional image of the round window membrane showing the gradient distribution of HPNPs; both condensed homogenous nuclear distribution of HPNPs (arrow head) and HPNP vesicles (arrow) were observed. B) Middle ear mucosal uptake of HPNPs. Condensed homogenous nuclear distribution of HPNPs (arrow head) and HPNP vesicles (arrow) were detected. C) Perinuclear distribution of HPNPs was observed in the spiral ganglion cell (arrow). D) HPNPs were found in the organ of Corti. Cytoplasmic distribution of HPNPs was observed in the hair cells, and both cytoplasmic and perinuclear distribution of HPNPs was detected in the supporting (border) cells. E) Both cytoplasmic and nuclear distribution of HPNPs was detected in the stria marginal cells, the typical tight junctions of the stria marginal cells are shown using F-actin staining (arrow). F) Abundant HPNPs were observed in the spiral ligament fibrocytes. G) Abundant HPNPs were detected in the endothelium of the stapedial artery including the nuclear HPNP vesicles (arrow).

Notes: Green: FITC-conjugated HPNPs. Red: F-actin stained by TRITC-conjugated phalloidin. Blue: nuclear staining by DAPI. Scale bar $=10 \mu \mathrm{m}$.

Abbreviations: BC, border cells; HPNPs, hyperbranched polylysine nanoparticles; IHC, inner hair cell; IS, inner side of the round window membrane; OHC, outer hair cell; OS, outer side of the round window membrane; I, 2, 3: row I, row 2, and row 3 of OHC. 


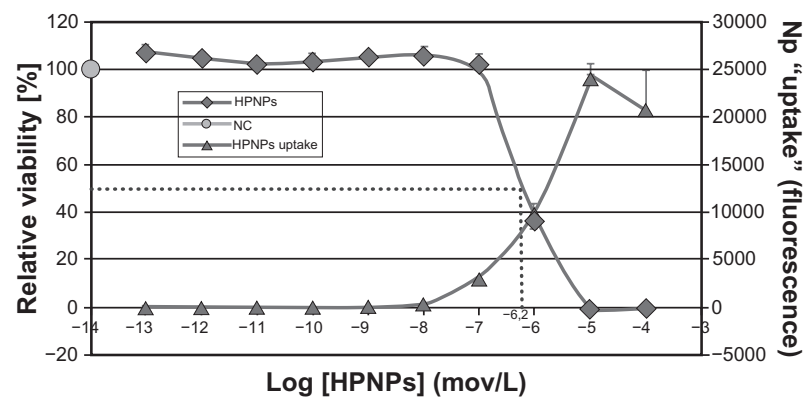

Figure 9 The cell viability of L929 mouse fibroblasts is dependent on the concentration of HPNPs applied. The $\mathrm{ED}_{50}$ was calculated as $10^{-6.2} \mathrm{~mol} / \mathrm{L}$ (dashed line). The internalization of the HPNPs is also concentration-dependent.

Abbreviations: NC, untreated control; HPNPs, hyperbranched polylysine nanoparticles.

The fluorescence signal merely indicated fluorescence associated with material adhering to the bottom of the microtiter well. Microscopic inspection showed that the cells were damaged, which led to binding of the HPNPs to the DNA such that the nuclei were brightly labeled, which corresponded to a strong fluorescence signal. As a cell death indicator, the cochlear cells stained by propidium iodide had a dot-like appearance in the perinuclear region (Figure 3B) which was different from that reported in the literature. ${ }^{29}$ It is obvious that the typical homogenous nuclear staining of propidium iodide indicated cell death. In primary cochlear cell cultures, higher concentrations of HPNPs incubation caused cell death (Figures 4 and 5). The dot-like perinuclear appearance of propidium iodide staining within the cochlear cells without nuclear staining suggested that these were viable cells (Figure 3B). The simultaneous nuclear distribution of HPNP vesicles and dot-like perinuclear appearance of propidium iodide (Figure 3B) also indicated active transport of HPNP in living cells. It should also be pointed out that HPNPs-containing vesicles are only detectable in living cells because passive diffusion of HPNPs into the nuclei following cell death will show homogenous distribution. As a result, nuclear entry of HPNPs was a meaningful biological process instead of a consequence of cell death.

Regarding the mechanism of nuclear import, there are potentially several pathways, such as nucleolin signaling, cellular membrane penetration, and the nuclear localization signal pathway, among others. ${ }^{30-33}$ One potential mechanism by which HPNPs mediate nuclear entry may be internalization and transport into the nucleus via binding to nucleolin. Nucleolin is a ubiquitous eukaryotic protein that is conserved from yeast to mammals, and is found in the nucleoli, nucleoplasm, and on the cell surface. ${ }^{34,35}$ Nucleolin is able to shuttle between the plasma membrane, cytoplasm, and nucleus, and regulates many aspects of DNA and RNA metabolism. ${ }^{34,36}$ It has been reported that nucleolin is the cell surface target of DNA nanoparticles, and that nucleolin is essential for internalization and/or transport of the DNA nanoparticles from the cell surface to the nucleus. ${ }^{30}$ This was also indicated in our study, as demonstrated by the HPNP vesicle pathway from the cytoplasm towards the nucleolin-positive nucleolus (Figure 6). A recent report showed that nucleolin-mediated cellular trafficking of DNA nanoparticles is lipid raft- and microtubule-dependent, and can be modulated by glucocorticoids. ${ }^{37}$ Another potential mechanism is that the nuclear envelope penetration or fusion is potentially involved in the nuclear internalization of HPNPs by cochlear cells. ${ }^{25,33,38}$ It is possible that the HPNPs internalized within the cytoplasm are retained and tethered to the inner surface of the vesicle, and thereafter transported into the nuclei by molecular machinery (such as dyneins) along cytoskeletal tracks. ${ }^{33,38}$ Nuclear localization signalmediated nuclear transport of HPNPs is also a potential
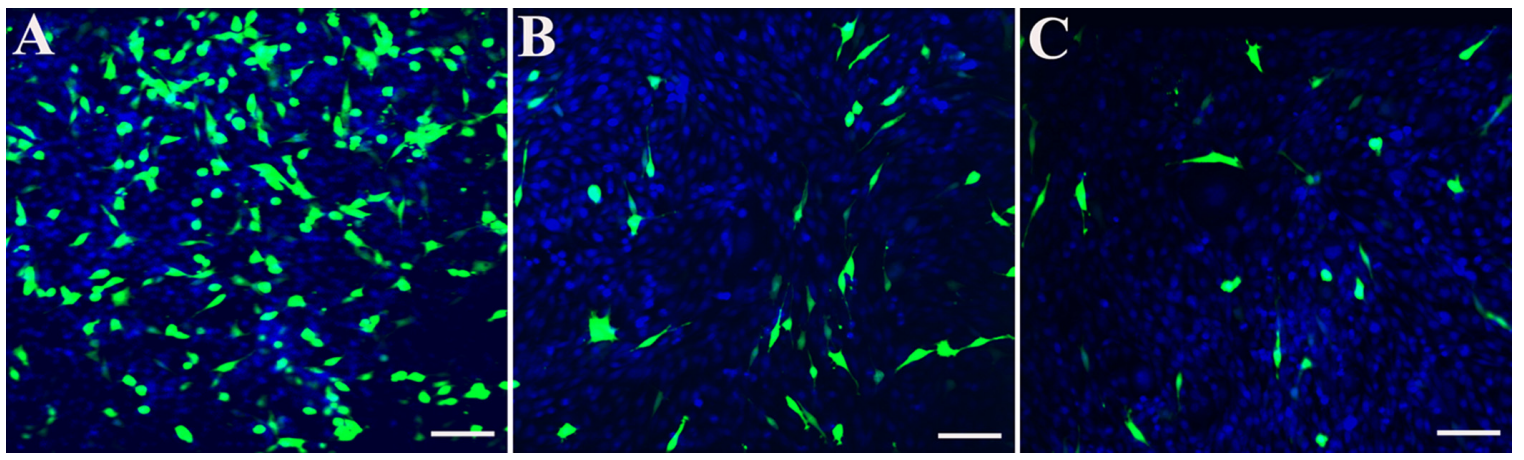

Figure 10 HPNP-mediated transfection in NIH 3T3 cells and primary cochlear cells with the pGeneClip ${ }^{\text {TM }}$ hMGFP plasmid observed by fluorescent microscopy. A) The transfection efficiency mediated by HPNPs at an N/P (w/w) ratio of $5: 1$ in NIH 3 T3 cells was $29.8 \%$. B) The transfection efficiency mediated by HPNPs at an N/P $(\mathrm{w} / \mathrm{w})$ ratio of $5: 1$ in cochlear cells was $8.7 \%$. C) Positive control, the transfection efficiency mediated by Lipofectamine ${ }^{\mathrm{TM}}$ in cochlear cells was $6.0 \%$, which is lower than the transfection efficiency mediated by HPNPs.

Notes: Green: Green fluorescent protein expression. Blue: nuclear staining by DAPI. Scale bar $=100 \mu \mathrm{m}$.

Abbreviation: HPNPs, hyperbranched polylysine nanoparticles. 
mechanism, which requires the presence of cytosolic factors and adenosine triphosphate. ${ }^{39,40} \mathrm{We}$ cannot rule out the possibility that HPNPs bind to specific cytosolic proteins in the primary newborn rat cochlea cells and pass through the nuclear pore complex. However, the present study did not prove or disprove this hypothesis.

Finally, the internalization of HPNPs by the cochlear cells was not specific for any cellular population. This did not meet our goal of targeted gene delivery into the cochlea. However, the functionalization of HPNPs with specific peptides for a definite cell population of the cochlea may improve the targetability of these nanoparticles. Specific targeting and higher binding affinity to spiral ganglion neurons has been observed in PEGylated polysome nanoparticles functionalized by a neurotrophin-derived peptide. ${ }^{41}$ HPNPs can also be included in other nanoparticles, such as lipid nanoparticles, to achieve both ideal targetability and efficient gene expression in cochlear cells.

\section{Conclusion}

In conclusion, efficient internalization of HPNPs was observed in both the cytoplasm and nucleus of cochlear cell culture, cochlear organotypic culture, and in vivo round window membranes. High transfection efficiencies were achieved in HPNP-mediated gene transfer in NIH 3T3 cells. These suggest that HPNPs have a potential application in gene delivery to the cochlea. To pass through the round window membrane and deliver genes into the cochlea efficiently, it is necessary to modify the nanoparticle surface to avoid early nuclear entry into the cells of the round window membrane.

\section{Acknowledgments}

This study was supported by the European Community Sixth Framework Programme on Research, Technological Development and Demonstration. The authors would like to thank Dr Markus Scholl, Ms Zuzana Kadlecova, and Professor Harm-Anton Klok from the Polytechnique Fédérale de Lausanne, Switzerland, for kindly providing the HPNPs used in this study.

\section{Disclosure}

The authors report no conflicts of interest in this work.

\section{References}

1. Husseman J, Raphael Y. Gene therapy in the inner ear using adenovirus vectors. Adv Otorhinolaryngol. 2009;66:37-51.

2. Kesser BW, Lalwani AK. Gene therapy and stem cell transplantation: Strategies for hearing restoration. Adv Otorhinolaryngol. 2009;66: 64-86.
3. Ryan AF, Mullen LM, Doherty JK. Cellular targeting for cochlear gene therapy. Adv Otorhinolaryngol. 2009;66:99-115.

4. Izumikawa M, Minoda R, Kawamoto K, et al. Auditory hair cell replacement and hearing improvement by Atoh1 gene therapy in deaf mammals. Nat Med. 2005;11:271-276.

5. Kawamoto K, Ishimoto S, Minoda R, Brough DE, Raphael Y. Math1 gene transfer generates new cochlear hair cells in mature guinea pigs in vivo. $J$ Neurosci. 2003;23:4395-4400.

6. Iizuka T, Kanzaki S, Mochizuki H, et al. Noninvasive in vivo delivery of transgene via adeno-associated virus into supporting cells of the neonatal mouse cochlea. Hum Gene Ther. 2008;19:384-390.

7. Liu Y, Okada T, Sheykholeslami K, et al. Specific and efficient transduction of cochlear inner hair cells with recombinant adenoassociated virus type 3 vector. Mol Ther. 2005;12:725-733.

8. Zhong L, Li B, Mah CS, et al. Next generation of adeno-associated virus 2 vectors: Point mutations in tyrosines lead to high-efficiency transduction at lower doses. Proc Natl Acad Sci U S A. 2008;105:7827-7832.

9. Bedrosian JC, Gratton MA, Brigande JV, Tang W, Landau J, Bennett J. In vivo delivery of recombinant viruses to the fetal murine cochlea: Transduction characteristics and long-term effects on auditory function. Mol Ther. 2006;14:328-335.

10. Derby ML, Sena-Esteves M, Breakefield XO, Corey DP. Gene transfer into the mammalian inner ear using HSV-1 and vaccinia virus vectors. Hear Res. 1999;134:1-8.

11. Praetorius M, Knipper M, Schick B, et al. A novel vestibular approach for gene transfer into the inner ear. Audiol Neurootol. 2002;7:324-334.

12. Braun S. Muscular gene transfer using nonviral vectors. Curr Gene Ther. 2008;8:391-405.

13. Tong H, Qin S, Fernandes JC, Li L, Dai K, Zhang X. Progress and prospects of chitosan and its derivatives as non-viral gene vectors in gene therapy. Curr Gene Ther. 2009;9:495-502.

14. Hacein-Bey-Abina S, von Kalle C, Schmidt M, et al. A serious adverse event after successful gene therapy for X-linked severe combined immunodeficiency. N Engl J Med. 2003;348:255-256.

15. Raper SE, Chirmule N, Lee FS, et al. Fatal systemic inflammatory response syndrome in a ornithine transcarbamylase deficient patient following adenoviral gene transfer. Mol Genet Metab. 2003;80: $148-158$.

16. Woods NB, Bottero V, Schmidt M, von Kalle C, Verma IM. Gene therapy: Therapeutic gene causing lymphoma. Nature. 2006;440:1123.

17. Niidome T, Huang L. Gene therapy progress and prospects: Nonviral vectors. Gene Ther. 2002;9:1647-1652.

18. Jean M, Smaoui F, Lavertu M, et al. Chitosan-plasmid nanoparticle formulations for IM and SC delivery of recombinant FGF-2 and PDGF-BB or generation of antibodies. Gene Ther. 2009;16: 1097-1110.

19. Wang Y, Gao S, Ye WH, Yoon HS, Yang YY. Co-delivery of drugs and DNA from cationic core-shell nanoparticles self-assembled from a biodegradable copolymer. Nat Mater. 2006;5:791-796.

20. Zou J, Saulnier P, Perrier T, et al. Distribution of lipid nanocapsules in different cochlear cell populations after round window membrane permeation. J Biomed Mater Res B Appl Biomater. 2008;87:10-18.

21. James MB, Giorgio TD. Nuclear-associated plasmid, but not cellassociated plasmid, is correlated with transgene expression in cultured mammalian cells. Mol Ther. 2000;1:339-346.

22. Tachibana R, Harashima H, Ide N, et al. Quantitative analysis of correlation between number of nuclear plasmids and gene expression activity after transfection with cationic liposomes. Pharm Res. 2002; 19:377-381.

23. Dean DA, Strong DD, Zimmer WE. Nuclear entry of nonviral vectors. Gene Ther. 2005;12:881-890.

24. Pollard H, Remy JS, Loussouarn G, Demolombe S, Behr JP, Escande D. Polyethylenimine but not cationic lipids promotes transgene delivery to the nucleus in mammalian cells. J Biol Chem. 1998;273:7507-7511.

25. Godbey WT, Wu KK, Mikos AG. Tracking the intracellular path of poly(ethylenimine)/DNA complexes for gene delivery. Proc Natl Acad Sci U S A. 1999;96:5177-5181. 
26. Carlisle RC, Bettinger T, Ogris M, Hale S, Mautner V, Seymour LW. Adenovirus hexon protein enhances nuclear delivery and increases transgene expression of polyethylenimine/plasmid DNA vectors. Mol Ther. 2001;4:473-483.

27. Scholl M, Nguyen TQ, Bruchmann B, Klok H-A. The thermal polymerization of amino acids revisited: Synthesis and structural characterization of hyperbranched polymers from L-lysine. J Polym Sci. 2007;45:5494-5508.

28. Scheper V, Wolf M, Scholl M, et al. Potential novel drug carriers for inner ear treatment: Hyperbranched polylysine and lipid nanocapsules. Nanomedicine (Lond). 2009;4:623-635.

29. Minami SB, Yamashita D, Schacht J, Miller JM. Calcineurin activation contributes to noise-induced hearing loss. J Neurosci Res. 2004; 78:383-392.

30. Chen X, Kube DM, Cooper MJ, Davis PB. Cell surface nucleolin serves as receptor for DNA nanoparticles composed of pegylated polylysine and DNA. Mol Ther. 2008;16:333-342.

31. Tkachenko AG, Xie H, Coleman D, et al. Multifunctional gold nanoparticle-peptide complexes for nuclear targeting. J Am Chem Soc. 2003;125:4700-4701.

32. Berry CC, de la Fuente JM, Mullin M, Chu SW, Curtis AS. Nuclear localization of HIV-1 tat functionalized gold nanoparticles. IEEE Trans Nanobioscience. 2007;6:262-269.
33. Verma A, Stellacci F. Effect of surface properties on nanoparticle-cell interactions. Small. 2010;6:12-21.

34. Ginisty H, Sicard H, Roger B, Bouvet P. Structure and functions of nucleolin. J Cell Sci. 1999;112(Pt 6):761-772.

35. Mongelard F, Bouvet P. Nucleolin: A multiFACe Ted protein. Trends Cell Biol. 2007;17:80-86.

36. Srivastava M, Pollard HB. Molecular dissection of nucleolin's role in growth and cell proliferation: New insights. FASEB J. 1999;13: 1911-1922.

37. Chen X, Shank S, Davis PB, Ziady AG. Nucleolin-mediated cellular trafficking of DNA nanoparticle is lipid raft and microtubule dependent and can be modulated by glucocorticoid. Mol Ther. 2010;19:93-102.

38. Godbey WT, Wu KK, Mikos AG. Poly(ethylenimine) and its role in gene delivery. J Control Release. 1999;60:149-160.

39. Cserpan I, Udvardy A. The mechanism of nuclear transport of natural or artificial transport substrates in digitonin-permeabilized cells. $J$ Cell Sci. 1995; 108(Pt 5):1849-1861.

40. Adam SA, Marr RS, Gerace L. Nuclear protein import in permeabilized mammalian cells requires soluble cytoplasmic factors. J Cell Biol. 1990; 111:807-816.

41. Roy S, Johnston AH, Newman TA, et al. Cell-specific targeting in the mouse inner ear using nanoparticles conjugated with a neurotrophinderived peptide ligand: Potential tool for drug delivery. Int J Pharm. 2010;390:214-224.
International Journal of Nanomedicine

\section{Publish your work in this journal}

The International Journal of Nanomedicine is an international, peerreviewed journal focusing on the application of nanotechnology in diagnostics, therapeutics, and drug delivery systems throughout the biomedical field. This journal is indexed on PubMed Central, MedLine, CAS, SciSearch ${ }^{\circledR}$, Current Contents ${ }^{\circledR} /$ Clinical Medicine,

\section{Dovepress}

Journal Citation Reports/Science Edition, EMBase, Scopus and the Elsevier Bibliographic databases. The manuscript management system is completely online and includes a very quick and fair peer-review system, which is all easy to use. Visit http://www.dovepress.com/ testimonials.php to read real quotes from published authors. 